\title{
Significance of Thinned Fruit as a Source of the Secondary Inoculum of Monilinia fructicola in California Nectarine Orchards
}

\author{
Chuanxue Hong, Department of Plant Pathology, University of California Davis, Kearney Agricultural Center, \\ Parlier, 93648; Brent A. Holtz, University of California Cooperative Extension, Madera, 93637; and David P. \\ Morgan and Themis J. Michailides, Department of Plant Pathology, University of California Davis, Kearney Ag- \\ ricultural Center, Parlier 93648
}

\begin{abstract}
Hong, C. X., Holtz, B. A., Morgan, D. P., and Michailides, T. J. 1997. Significance of thinned fruit as a source of the secondary inoculum of Monilinia fructicola in California nectarine orchards. Plant Dis. 81:519-524.

The significance of thinned fruit as a source of secondary inoculum in the spread of brown rot, caused by Monilinia fructicola, under semi-arid weather conditions of the San Joaquin Valley in California, was investigated in seven nectarine orchards in 1995 and 1996. Between 6 and 60\% (depending on the orchard) of thinned fruit showed sporulation by M. fructicola. Brown rot was significantly less severe at preharvest (five orchards) and postharvest (one orchard) on fruit harvested from trees in plots from which thinned fruit were completely removed than on those in plots from which thinned fruit were not removed. M. fructicola sporulated more frequently on thinned fruit placed into irrigation trenches than on those left on the dry berms in tree rows. The incidence of preharvest fruit brown rot increased exponentially as the density of thinned fruit increased on the orchard floor. These results suggest that thinned fruit left on the floor of nectarine orchards can be a significant inoculum source of secondary infections. Removal or destruction of thinned fruit should reduce brown rot in nectarine and possibly other stone fruit orchards under semi-arid California conditions.
\end{abstract}

Additional keywords: disease control, epidemiology, Prunus, stone fruits

Brown rot, caused by Monilinia fructicola (G. Wint.) Honey, is one of the most destructive diseases of stone fruits (Prunus L.) in the United States $(22,28,40)$, Canada (1-3), Australia (5-7), and New Zealand $(4,8)$. M. fructicola usually causes blossom blight in the spring, which develops into a twig blight and canker and provides inoculum for latent infection of green fruit (15,26,35,37, and T. J. Michailides, unpublished data). Subsequently, brown rot develops on fruit at the end of the season (harvest) and after harvest (during storage and transport to markets) (5). Blossom blight and fruit brown rot are the most important phases epidemiologically and economically.

Inoculum sources for primary infection of blossoms by $M$. fructicola have been extensively investigated under various weather conditions $(1,5,11-13,18,22)$ since the late nineteenth century (30). Comparatively little has been done on the relationship between sources of inoculum and infection of immature and mature fruit.

Corresponding authors: Chuanxue Hong and Themis J. Michailides

E-mail: chuanxue@uckac.edu and

themis@uckac.edu, respectively

Accepted for publication 10 February 1997.

Publication no. D-1997-0324-09R

(C) 1997 The American Phytopathological Society
Pioneer work on the sources of secondary inoculum of brown rot was done by Landgraf and Zehr (22) in South Carolina and Biggs and Northover (1) in Canada. They considered non-abscised, aborted fruit in trees and thinned fruit on the orchard floor as important sources of the secondary inoculum for fruit brown rot under their humid climates $(1,22)$. However, there are no reports on the contribution and importance of thinned fruit as a source of the secondary inoculum under the semi-arid weather conditions of California.

This paper reports the investigation of the importance of thinned fruit as a source of secondary inoculum for fruit brown rot in seven nectarine (Prunus persica var. nectarina (Ait.) Maxim.) orchards in the semi-arid San Joaquin Valley of California in 1995 and 1996. The specific objectives of this study were to determine the incidence of $M$. fructicola conidial sporulation on thinned fruit, study the significance of thinned fruit as a source of the secondary inoculum of $M$. fructicola in irrigated nectarine orchards, and determine the relationship between the density of thinned fruit on the orchard floor and the incidence of fruit brown rot.

\section{MATERIALS AND METHODS}

Orchards and weather data. Field experiments were conducted in five nectarine orchards in 1995 (coded as 951 to 955) and two in 1996 (coded as 961 and 962) (Table
1), located near Parlier, Reedley, or Easton, all in Fresno County. Nectarine cultivars included in the experiments were Fantasia (orchards 951, 953, and 962), which is one of the latest maturing freestone nectarine cultivars, Summer Grand (orchards 954 and 961), which is the most common cultivar in production in California, August Red (orchard 952), and May Diamond (orchard 955) (Table 1). Trees were planted 5 to 6 by 5 to $6 \mathrm{~m}$ and ranged in age from 9 to 22 years during the seasons when experiments were conducted. Strips of 1$\mathrm{m}$-wide reflective plastic film were placed between tree rows in orchards 961 and 962 in early June to enhance the fruit color.

Two to three fungicide sprays were applied to control blossom blight from February to March (except for orchards 952 and 953) in 1995 and 1996, and one to two sprays were applied to control fruit brown rot before harvest in 1995 (Table 1). Fungicides applied included benomyl, captan, chlorothalonil, iprodione, myclobutanil, and triforine $(4,22,29)$.

Orchards were irrigated from late March until the end of October (data after harvest not shown); irrigation schedules varied from orchard to orchard (Table 1). Usually, orchards were irrigated every 5 to 20 days, resulting in four to seven irrigations between fruit thinning and harvest. Local weather data were obtained from the California Irrigation Management Information System (CIMIS).

Effect of completely removing thinned fruit on brown rot. Experiment A was conducted in three orchards (951, 952 and 953) in 1995 and two orchards (961 and 962 ) in 1996. Treatments consisted of A1, in which thinned fruit were completely removed from the plots, and A2, in which thinned fruit were not removed and were supplemented by an equal amount of thinned fruit obtained from A1 plots. In orchard 962, a third treatment, A3, was included, in which fruit thinned by the grower were left undisturbed. There were three replicated plots per treatment in all orchards, except for 952 and 953, which had four replications per treatment. Each plot consisted of $8 \times 8$ trees. Treatments in each orchard were arranged in a randomized block design.

Before fruit thinning, the four center trees and four corner trees in each plot were flagged. Green fruit were thinned 
manually by growers and counted under the four center trees in each plot. Stage of fruit development at thinning was determined by cutting fruit, and no fruit were thinned before pit-hardening in any of our experimental orchards. Eleven to fifteen days after thinning, 200 thinned fruit were selected randomly in the irrigation trenches and on the dry berms under each of 4 center trees in orchards 951 and 953. The fruit were examined individually for visible conidial sporulation of $M$. fructicola, and the number of thinned fruit exhibiting sporulation recorded. Thinned fruit were examined only in the trenches around the 4 center trees in A2 plots in orchards 961 and 962. Thinned fruit with sporulation of M. fructicola were recorded weekly in orchard 961, but only twice in orchard 962. The incidence of thinned fruit exhibiting the sporulation in each plot was calculated and the data were analyzed using Proc analysis of variance (ANOVA) of SAS (Version 8.6e, SAS Institute Inc., Cary, NC). Means were separated by Fisher's least significant difference at $P=0.05$.

Fruit brown rot was assessed by observing sporulation of M. fructicola on 200 fruit selected arbitrarily in each of the 4 center trees in all plots, either once or twice before the first fruit harvest. Because fruit mature at different times, several harvests occur per season. The incidence of preharvest fruit brown rot was calculated for each replicated plot and data were analyzed using Proc ANOVA and means were also separated by Fisher's least significant difference at $P=0.05$.

Fifty fruit with no obvious symptoms of brown rot were harvested from each of the 4 center trees in each replicate, placed into a paper box (2 layers with 25 fruit per layer), transported to the Kearney Agricultural Center postharvest laboratory, and stored at $4^{\circ} \mathrm{C}$ for 7 days to restrict
Rhizopus rot (10) and simulate commercial storage. The fruit were then incubated at $20^{\circ} \mathrm{C}$ and $>95 \%$ relative humidity for 3 days before examining for postharvest diseases. Brown rot and other diseases were recorded every other day for 3 to 5 days. The incidence of postharvest fruit brown rot was calculated for each plot and the incidence data of each orchard and assessment were also analyzed using Proc ANOVA. Treatment mean incidence data of 5 orchards and 2 to 3 assessments were pooled and further analyzed using the sign test (20).
Effect of moving thinned fruit from berms to irrigation trenches on fruit brown rot. Experiment $B$ was carried out in orchards 954 and 955 in 1995 . Treatments included in this trial were $\mathrm{B} 1$, in which thinned fruit were moved from berms into irrigation trenches, and $\mathrm{B} 2$, in which thinned fruit were not disturbed. There were three $8 \times 8$ tree replicates of each treatment and the two treatments were arranged in a randomized block design. Sporulation of $M$. fructicola on thinned fruit was assessed by examining 200 fruit in the trenches, and 11 to 26 naturally
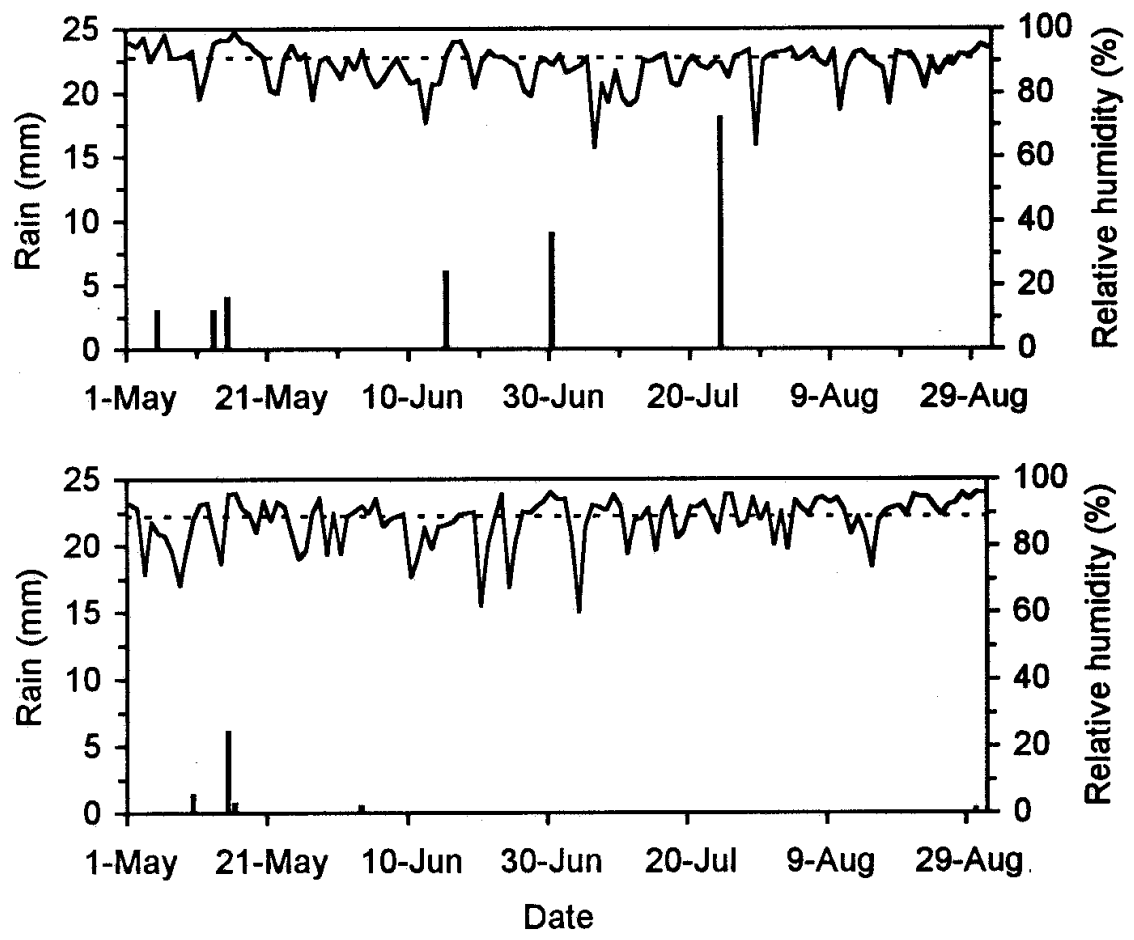

Fig. 1. Daily rainfall and maximum relative humidity at a representative weather station (Parlier, California), during May to August of 1995 (top) and 1996 (bottom).

Table 1. Fungicide applications and irrigation schedule applied of orchards used in the study

\begin{tabular}{|c|c|c|c|c|c|c|c|}
\hline Orchard code & 951 & $952^{x}$ & 953 & 954 & 955 & 961 & 962 \\
\hline Location & KAC & Reedley & Reedley & Parlier & Parlier & Parlier & Easton \\
\hline Nectarine cultivar & Fantasia & August Red & Fantasia & Summer Grand & May Diamond & Summer Grand & Fantasia \\
\hline Tree age (years) & 21 & 9 & 17 & 17 & 10 & 18 & 22 \\
\hline Thinning date & $4 / 27^{y}$ & $6 / 6$ & $5 / 17$ & $5 / 3$ & $5 / 9$ & $5 / 13$ & $5 / 18$ \\
\hline No. of thinned fruit/tree & 960 & 162 & 314 & 1547 & 351 & 2114 & 500 \\
\hline 1st blossom spray & $2 / 13$ benomyl & & & $2 / 12$ & $2 / 12$ & $2 / 24$ & $2 / 22$ \\
\hline (date and fungicides) & /iprodione & $\mathrm{NA}^{\mathrm{z}}$ & NA & iprodione & iprodione & iprodione & iprodione \\
\hline $\begin{array}{l}\text { 2nd blossom spray } \\
\text { (date and fungicides) }\end{array}$ & $\begin{array}{r}2 / 17 \\
\text { iprodione }\end{array}$ & NA & NA & $\begin{array}{l}\text { 2/21 benomyl/ } \\
\text { chlorothalonil }\end{array}$ & $\begin{array}{l}\text { 2/21 benomyl/ } \\
\text { chlorothalonil }\end{array}$ & $\begin{array}{c}\text { myclobutanil/ } \\
\text { captan }\end{array}$ & $\begin{array}{r}3 / 1 \\
\text { iprodione }\end{array}$ \\
\hline $\begin{array}{l}\text { 3rd blossom spray } \\
\text { (date and fungicides) }\end{array}$ & NA & NA & NA & $\begin{array}{r}3 / 8 \\
\text { captan }\end{array}$ & $\begin{array}{r}3 / 8 \\
\text { captan }\end{array}$ & $\begin{array}{c}3 / 9 \\
\text { chlorothalonil }\end{array}$ & $\begin{array}{r}3 / 8 \\
\text { benomyl }\end{array}$ \\
\hline $\begin{array}{l}\text { 1st preharvest spray } \\
\text { (date and fungicides) }\end{array}$ & $\begin{array}{r}6 / 29 \\
\text { iprodione }\end{array}$ & $\begin{array}{r}7 / 18 \\
\text { triforine }\end{array}$ & $\begin{array}{r}6 / 23 \\
\text { triforine }\end{array}$ & $\begin{array}{r}6 / 19 \\
\text { triforine }\end{array}$ & $\begin{array}{r}6 / 16 \\
\text { triforine }\end{array}$ & cmiturinaiomiti & Denomy \\
\hline $\begin{array}{l}\text { 2nd preharvest spray } \\
\text { (date and fungicides) }\end{array}$ & $\begin{array}{r}7 / 7 \\
\text { triforine }\end{array}$ & NA & $\begin{array}{r}7 / 4 \\
\text { triforine }\end{array}$ & NA & (2) & NIA & $N A$ \\
\hline $\begin{array}{l}\text { Irrigation dates } \\
\text { Intes) }\end{array}$ & $\begin{array}{r}5 / 1,10,22, \\
6 / 1,8,19, \\
7 / 3,10\end{array}$ & $\begin{array}{r}4 / 25, \\
5 / 1,11,25, \\
6 / 9,16,22, \\
7 / 2,7,11,15, \\
7 / 28,8 / 15\end{array}$ & $\begin{array}{r}3 / 22,4 / 25, \\
5 / 22, \\
6 / 5,20,25, \\
7 / 9,15,20\end{array}$ & $\begin{array}{r}5 / 5,27, \\
6 / 14,26, \\
7 / 7,18\end{array}$ & $\begin{array}{r}5 / 4,26, \\
6 / 10,28, \\
7 / 16,29\end{array}$ & $\begin{array}{r}4 / 18, \\
5 / 3,17, \\
6 / 2,13,30, \\
7 / 2,21\end{array}$ & $\begin{array}{r}4 / 7,23, \\
5 / 4,17,29, \\
6 / 8,17,26, \\
7 / 4,10\end{array}$ \\
\hline
\end{tabular}

\footnotetext{
${ }^{x}$ In orchard 952, every other tree row was flooded with each irrigation in July.

y Month/date(s).
}

${ }^{\mathrm{z}}$ Fungicides were not applied. 
fallen fruit found on the berm under each of 4 center trees in either orchard, as described previously. Pre- and postharvest fruit brown rot in these orchards were assessed and the data were analyzed as in experiment A.

Relationship between fruit brown rot and thinned fruit in orchards with nectarine cultivars of the same maturity. Since there is no apparent difference in susceptibility among nectarine cultivars to brown rot (28), disease incidences of different cultivars of the same maturity were compared. Nectarine fruit in orchards 951 , 953, 954, and 955 matured and were harvested in early- to mid-July, so data of preharvest fruit brown rot in A2 plots in orchards 951 and 953, and B2 plots in orchards 954 and 955, were pooled. The density of thinned fruit in A2 plots was calculated by doubling the orchard average number of thinned fruit per tree, since these plots received about equal amounts of thinned fruit moved from A1 plots in each orchard. The relationship between incidence of brown rot and the number of thinned fruit per tree was examined with Proc REG of SAS, after transforming the disease incidence data with the natural log. Similarly, the density of thinned fruit was calculated for A2 plots of orchards 961 and 962.

\section{RESULTS}

Weather data. The Parlier CIMIS station was located closest to the field experiments conducted in 1995 and in 1996. Daily rainfall and maximum relative humidity at the Parlier weather station from 1 May to 31 August, the seasonal time of nectarine fruit pit hardening and maturing in 1995 and 1996, are shown in Fig. 1. There were only 6 days of precipitation with a total of $43 \mathrm{~mm}$ rainfall from May to August 1995, and only 5 days of precipitation with a total of $8.9 \mathrm{~mm}$ rainfall during the same period in 1996 . The daily maximum relative humidity ranged from 63 to 99\% from May to August of 1995, and from 60 to $96 \%$ over the same 4 months in 1996. Daily maximum relative humidity was less than $90 \%$ over half of the periods in 1995 and 1996, with the weather generally being drier in 1996.

Effect of completely removing thinned fruit on brown rot. Green fruit were thinned at pit-hardening stage in all the orchards, but thinning dates differed among cultivars, orchards, and seasons (Table 1). Between 162 and 2,114 fruit per tree were thinned, depending mainly on the cultivar, season, and grower's strategy and preference.

The incidence of thinned fruit showing sporulation of $M$. fructicola was higher in the irrigation trenches than on the dry berms in orchards 951 and 953 (Table 2). The incidence of thinned fruit showing sporulation of $M$. fructicola increased in the first 3 weeks after fruit thinning and then declined in orchard 961 (Fig. 2).

Preharvest fruit brown rot was more severe in A2 plots, where thinned fruit were added, than in A1 plots, where the fruit were completely removed in orchards 951 and 952 at the first disease assessment, orchard 953 at the second assessment (Fig. 3), and in orchards 961 and 962 (Fig. 4).

The incidence of postharvest brown rot was significantly higher on the fruit collected from A2 plots than on fruit from A1 plots or A3 plots (Fig. 4). The sign test (20) of combined data from the five orchards for the two to three assessments of postharvest brown rot further demonstrated that the probability of observing postharvest brown rot was higher on fruit from A2 plots than on fruit from A1 plots in all orchards and assessments (all postharvest assessments, $n=14$ ) is 0.0002 ; the postharvest brown rot was significantly reduced by the practice of completely removing thinned fruit from plots. Other diseases observed included Rhizopus rot in 1995, and Botrytis and Rhizopus rots in 1996. Rhizopus rot $(3.5 \%)$ was the only other disease observed on the fruit collected from orchard 952 at the last assessment in 1995 . Botrytis rot $(0.2 \%)$ was observed on fruit collected from orchards 961 and 962 , whereas Rhizopus rot $(0.2 \%)$ was observed only on the fruit collected from orchard 962 at the last assessment.

Effect of moving thinned fruit from berms to irrigation trenches on fruit brown rot. The incidence of thinned fruit showing sporulation of $M$. fructicola was higher in the irrigation trenches than on the dry berms in orchards 954 and 955 (Table 2). No differences were observed between the incidence of both pre- and postharvest brown rot on fruit from B1 and B2 plots (data not shown).

Relationship between brown rot and thinned fruit in orchards with nectarine cultivars of the same maturity. Preharvest brown rot increased as the number of thinned fruit per tree increased in orchards in 1995 (Fig. 5). The relationship between brown rot incidence $(y, \%)$ and the number of thinned fruit per tree $(x)$ was best described by the equation $y=e^{0.0012 x}(P=$ $\left.0.0466, R^{2}=0.91\right)$. Orchard 952 was excluded from the regression analysis because green fruit were thinned and mature fruit were harvested about 1.5 months later than the fruit in the other orchards. A similar relationship was observed in 1996; in orchard 961, both thinned fruit $(4,228 /$ tree $)$ and incidence of postharvest brown rot $(13.5 \%)$ at the second disease

Table 2. Sporulation of Monilinia fructicola on thinned nectarine fruit in irrigation trenches and on dry berms in four irrigated orchards (1995) and one orchard (1996)

\begin{tabular}{lcccc}
\hline & & \multicolumn{2}{c}{ Thinned fruit exhibiting M. fructicola conidial sporulation (\%) } \\
\cline { 2 - 5 } Orchard & Exp. & Date examined & Trenches & Berms \\
\hline 951 & A & 10 May & $57.9 \mathrm{a}^{\mathrm{x}}$ & $37.6 \mathrm{~b}$ \\
953 & A & 1 June & $6.3 \mathrm{a}$ & $2.9 \mathrm{~b}$ \\
954 & B & June & $56.3 \mathrm{a}$ & $19.4 \mathrm{~b}^{\mathrm{y}}$ \\
954 & B June & $60.3 \mathrm{a}$ & $20.5 \mathrm{~b}^{\mathrm{y}}$ \\
955 & B & 1 June & $24.2 \mathrm{a}$ & $13.9 \mathrm{~b}^{\mathrm{y}}$ \\
962 & B & 18 June & 13.0 & ND $^{\mathrm{z}}$ \\
962 & A & 3 July & 4.7 & ND \\
\hline
\end{tabular}

x Values, followed with different letters within a row, differed significantly according to Fisher's least significant difference test at $P=0.05$.

${ }^{y}$ On which naturally fallen fruit was assessed for M. fructicola conidial sporulation.

z Not determined.

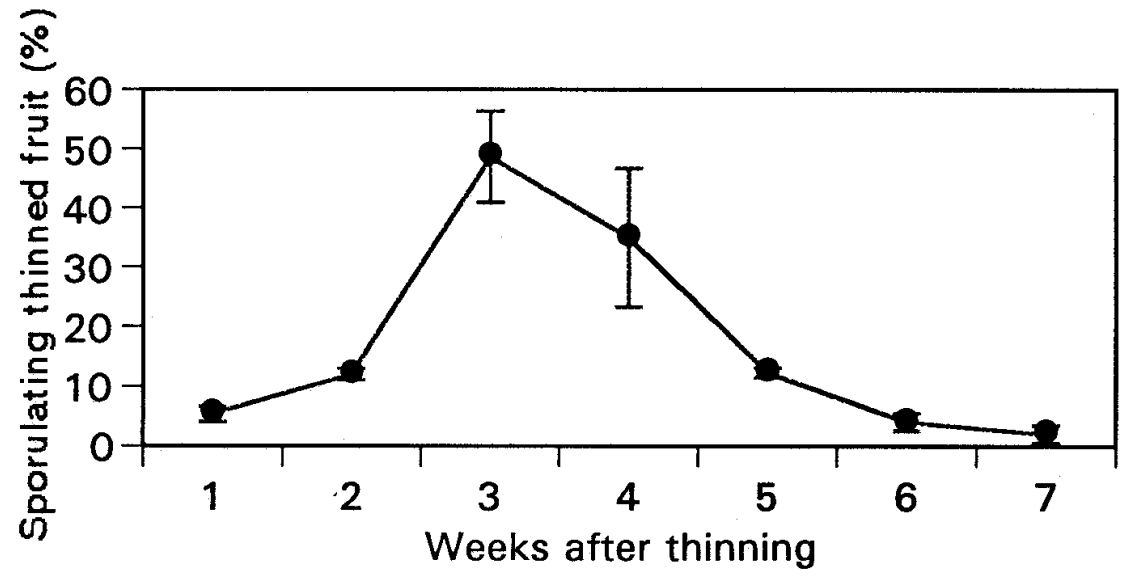

Fig. 2. Incidence of thinned fruit sporulating with Monilinia fructicola after thinning of nectarine (cv. Summer Grand) fruit in orchard 961, Parlier, California, 1996. Green fruit were thinned on 13 May. Vertical bars are the standard errors of the means. 

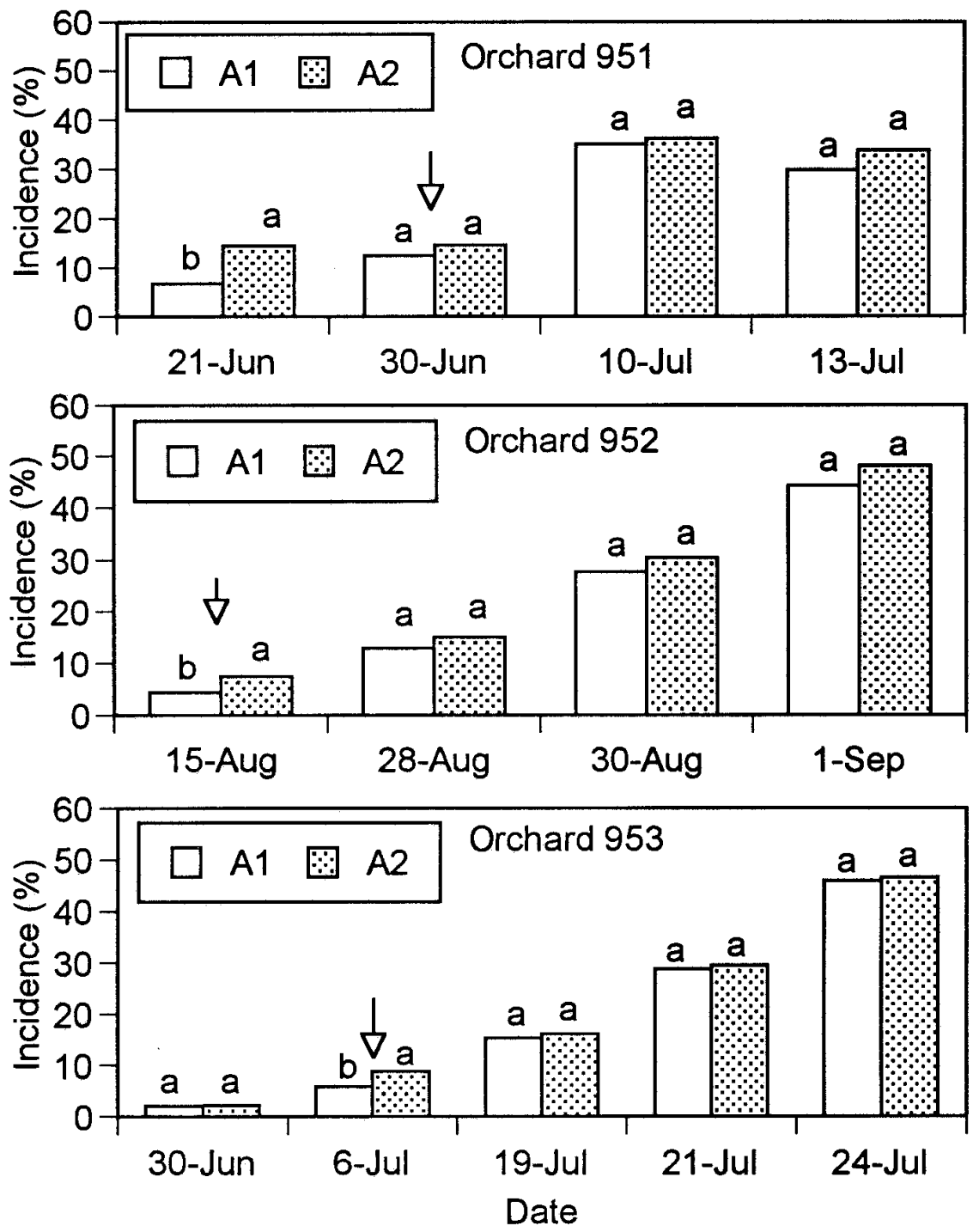

Fig. 3. Pre- and postharvest brown rot by Monilinia fructicola on nectarine fruit from A1 plots, from which thinned fruit were completely removed, and from A2 plots, from which thinned fruit were not removed and were supplemented by an equal amount of thinned fruit obtained from A1 plots, in orchard 951(cv. Fantasia) at the Kearney Agricultural Center, and orchards 952 (cv. August Red) and 953 (cv. Fantasia), near Reedley, California, 1995. Arrows indicate the dates of fruit harvest for determining postharvest diseases. Only bars to the right of the arrow represent postharvest assessment (in the lab). Bars topped by different letters within a date differed significantly according to Fisher's least significant difference test at $P=0.05$.

assessment were greater $(P<0.05)$ than those in orchard $962(1,000$ thinned fruit/tree and $9.7 \%$ postharvest brown rot).

\section{DISCUSSION}

Epidemiologically, brown rot of stone fruit is a polycyclic disease (5), and its fruit rot phase is characterized by latent infections $(8,15,16,19,26,35,37,39$, and $\mathrm{T}$. J. Michailides, unpublished data). In California, latent infections are facilitated by semi-arid weather conditions, particularly in drier seasons such as 1996. This conclusion is supported by the fact that brown rot was much less severe on fruit in trees before harvest than after harvest. Additionally, more fruit had sporulation of $M$. fructicola in orchards in 1995 (4.3 to $14.6 \%$ ) than in $1996(0.0$ to $0.5 \%)$, but the incidences of postharvest brown rot were comparable for 1995 (15.1 to 56.7\%) and 1996 ( 29.5 to $45.5 \%)$. Therefore, local weather conditions may have reduced the number of infection cycles per year. It is not unusual to have dry weather in the San Joaquin Valley during the spring and summer. Thus, conidia of $M$. fructicola produced on maturing fruit in trees are less important to the secondary spread of fruit brown rot under the semi-arid weather conditions, such as that of California, than in more humid climates, such as those of Canada (1) and South Carolina (22).

Dry weather conditions also limit some of the other sources of the secondary inoculum for fruit brown rot. Over the last 2 years, we observed that most aborted fruit dropped from trees before thinning. Nonabscised, aborted fruit were either very rarely observed in trees or mostly dried up following thinning, because of low humidity and poor rainfall during the seasons $(\mathrm{C}$. $\mathrm{X}$. Hong and T. J. Michailides, unpublished data). This dry weather also prevented sporulation of $M$. fructicola on blighted flowers. Therefore, non-abscised, aborted fruit and blossoms blighted by $M$. fructicola are unlikely to be important sources of the secondary inoculum for fruit brown rot in California orchards. This situation also differs from observations made in more humid areas $(1,22)$.

Extensive and intensive sporulation of M. fructicola on thinned fruit was observed in orchards both in South Carolina and Canada, so that thinned fruit was considered an important source of secondary inoculum in those areas $(1,22)$. Our study further quantified the importance of this inoculum source. Pre- and postharvest fruit brown rot was significantly reduced by completely removing the thinned fruit from 1,600 to $2,300 \mathrm{~m}^{2}$ plots in all five orchards in 1995 and 1996. The importance of thinned fruit as a source of the secondary inoculum might have been reduced by applying fungicides in orchards 951, 952 and 953, and by covering part of thinned fruit with reflective plastic film beginning in early June in orchards 961 and 962. Even under these circumstances, removal of thinned fruit resulted in significant reduction of brown rot at harvest (Figs. 3 and 4). Conidia of $M$. fructicola are airborne $(14,17,21)$ and also can be transported by various vectors $(9,21,25,27,36)$. Consequently, some interplot interference occurred due to airborne conidia that traveled across the plot borders from plots A2 to $\mathrm{A} 1$, and from neighboring orchards. Therefore, the significance of thinned fruit as a source of secondary inoculum for fruit brown rot may have been greater if fungicides had not been applied and the experimental plot had been larger in size.

Dry weather conditions suppress the sporulation of $M$. fructicola on infected tissue in trees in California orchards. These dry weather conditions, however, require growers to irrigate their orchards for maximum fruit production. Regular irrigation provides an ideal microclimate for infection by and sporulation of $M$. fructicola to occur on thinned fruit, and expedites the dispersal of conidia from sporulating thinned fruit to those that had been uninfected. The fact that more fruit initially sporulated in the irrigation trenches than on the dry berms provides direct evidence that irrigation water enhances sporulation of $M$. fructicola on thinned fruit. This fact also indirectly supports our observations that the sporulation was very rarely seen on non-abscised aborted fruit and blighted blossoms in trees during fruit maturing.

Irrigation water also disturbs insect 

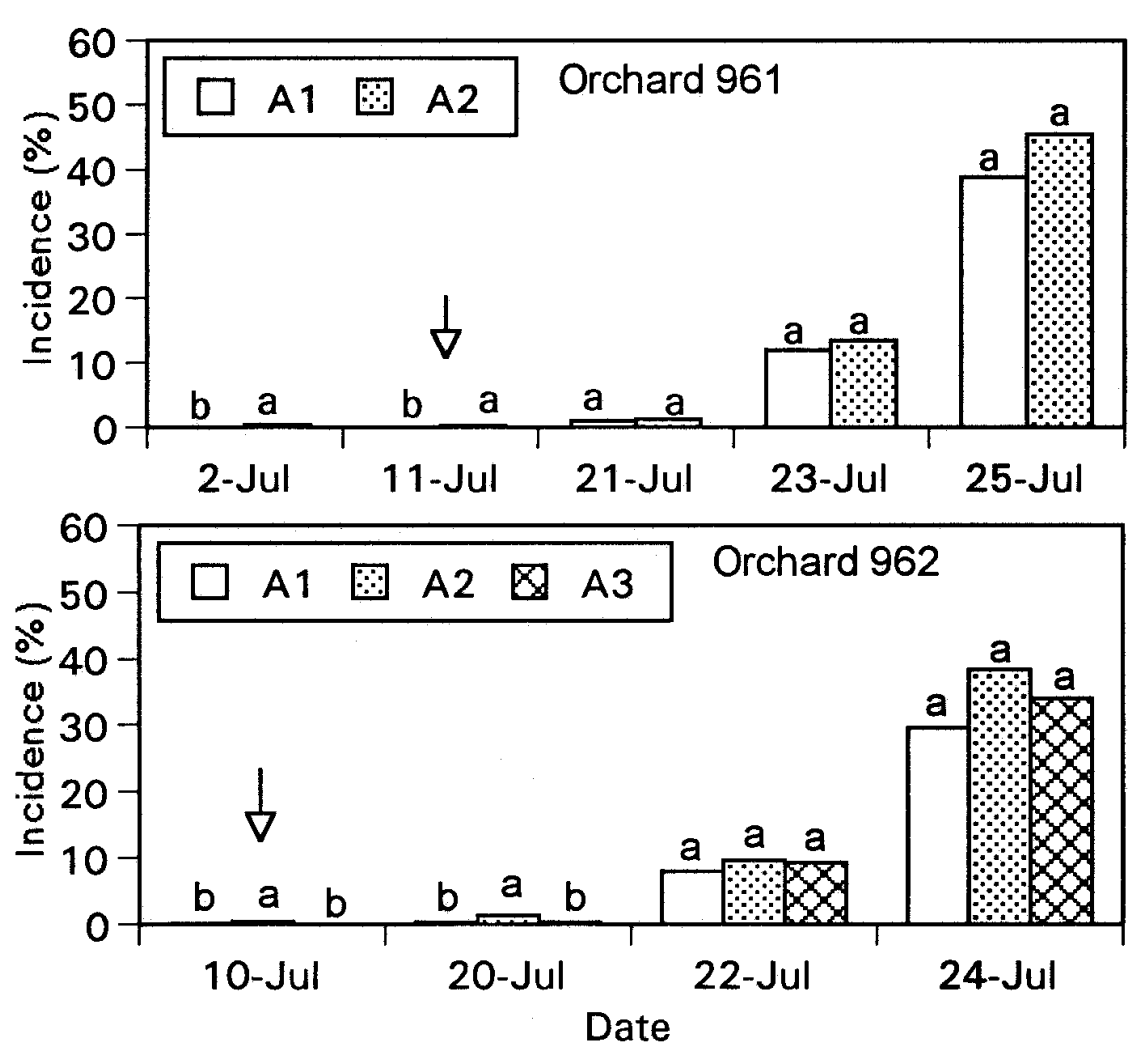

Fig. 4. Pre- and postharvest brown rot by Monilinia fructicola on nectarine fruit from A1 plots, from which thinned fruit were completely removed, from A2 plots, from which thinned fruit were not removed and were supplemented by an equal amount of thinned fruit obtained from A1 plots, and from A3 plots, in which thinned fruit were left undisturbed, in orchard 961 (cv. Summer Grand), Parlier, and orchard 962 (cv. Fantasia), Easton, California, 1996. Arrows indicate the dates of fruit harvest for determining postharvest diseases. Only bars to the right of the arrow represent postharvest assessment (in the lab). Bars topped by different letters within a date differed significantly according to Fisher's least significant difference test at $P=0.05$.

vectors and drives them away from the sporulating thinned fruit in the irrigation trenches $(18,34)$. Some of these insects (nitidulid beetles, thrips, and vineyard flies) are not only able to transport the conidia from infected thinned fruit to the surface of healthy fruit on trees, but also able to facilitate infection of fruit by creating wounds (34). The latter situation is particularly important to the fruit rot phase of brown rot because it increases fruit susceptibility (38), and is extremely important to the epidemiology of brown rot under dry weather conditions (18). The high efficiency of dispersal and subsequent infection by the conidia of $M$. fructicola produced on thinned fruit might also have contributed to the importance of this substrate as a major secondary inoculum supply in comparison with other possible sources for fruit brown rot epidemics in California orchards.

The high incidence of thinned fruit with sporulation of $M$. fructicola and their high density per tree further signify their importance as a major source of inoculum. In addition, preliminary experiments to quantify sporulation on sampled sporulating thinned fruit indicated that a minimum of 3.5 to 11.7 million conidia of $M$. fructicola were produced per fruit, although the pro-

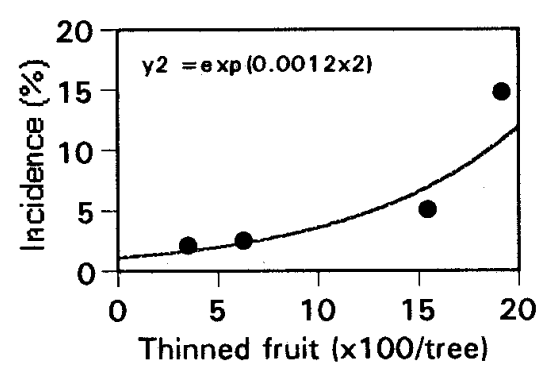

Fig. 5. The relationship between preharvest fruit brown rot caused by Monilinia fructicola and thinned fruit in four experiment orchards of different cultivars of the same maturity (early to middle July), 1995. Disease incidence data from A2 plots in orchards 951 and 953 and B2 plots in orchards 954 and 955 were pooled. The density of thinned fruit in the A2 plots was calculated by doubling the orchard average numbers of thinned fruit per tree in the same orchards, since A2 plots received equal amounts of thinned fruit from A1 plots.

\section{ACKNOWLEDGMENTS}

This research was supported in part by a grant from the University of California Integrated Pest Management Project, the California Tree Fruit Agreement, and California Prune Board. We thank G. Bergen in Parlier, Surabian Packing in Reedley, and H. A. Kaprielian in Easton for allowing us to conduct the experiments in their orchards. Our thanks extend to D. Rice for sharing the experimental orchard and to J. Chevalier for the support in the field experiments.

\section{LITERATURE CITED}

1. Biggs, A. R., and Northover, J. 1985. Inoculum sources for Monilinia fructicola in Ontario peach orchards. Can. J. Plant Pathol. 7:302-307.

2. Biggs, A. R., and Northover, J. 1988. Influence of temperature and wetness duration on infection of peach and sweet cherry fruits by Monilinia fructicola. Phytopathology 78:1352-1356.

3. Biggs, A. R., and Northover, J. 1988. Early and late-season susceptibility of peach fruits to Monilinia fructicola. Plant Dis. 72:10701074.

4. Braithwaite, M., Elmer, P. A. G., Saville, D. J., Boyd-Wilson, K. S. H., and Whelan, H. G. 1995. Reduced sensitivity to DMI fungicides in Monilinia fructicola and the efficacy of DMI fungicides for blossom blight control. Pages 17-21, in: Proc. N.Z. Plant Prot. Conf., 48th, New Zealand.

5. Byrde, R. J. W., and Willetts, H. J. 1977. The Brown Rot Fungi of Fruit: Their Biology and Control. Pergamon Press. Oxford and New York.

6. Corbin, J. B. 1963. Factors determining the length of the incubation period of Monilinia fructicola (Wint.) Honey in fruits of Prunus spp. Aust. J. Agric. Res. 14:51-60.

7. Corbin, J. B., and Cruickshank, I. A. M. 1963. Environment and sporulation in phytopathogenic fungi. V. Monilinia fructicola (Wint.) Honey: effect of water relations on regeneration of conidia in vivo. Aust. J. Biol. Sci. 16:99-110.

8. Cruickshank, R. H., and Wade, G. C. 1992. The activation of latent infections of Monilinia fructicola on apricots by volatiles from the ripening fruit. J. Phytopathology 136:107-112.

9. Ellis, E. C., Penman, D. R., and Gaunt, R. E. 1988. Thrips as potential vectors of brown rot of stone fruit in New Zealand. Pages 286-287 in: Proc. N.Z. Weed and Pest Control Conf., 
41st, New Zealand

10. Hawker, L. E., Hepden, P. M., and Perkins, S. M. 1957. The inhibitory effect of low temperature on early stage of zygospore production in Rhizopus sexualis. J. Gen. Microbiol. 17:758-767.

11. Holtz, B. A., Michailides, T. J., and Kolliker, R. 1995. Thinned infected stone fruit as inoculum source of Monilinia fructicola in California. (Abstr.) Phytopathology 85:1194.

12. Hong, C. X., Michailides, T. J., and Holtz, B. A. 1996. Survey of primary inoculum of brown rot in stone fruit orchards in the San Joaquin Valley of California. (Abstr.) Phytopathology $86:$ S110.

13. Hong, C. X., Michailides, T. J., and Holtz, B. A. 1996. Survival of Monilinia fructicola in mummified fruit in the San Joaquin Valley of California. (Abstr.) Phytopathology 86:S4.

14. Jenkins, P. T. 1965. The dispersal of conidia of Sclerotinia fructicola (Wint.) Rehm. Aust. J. Agric. Res. 16:627-633.

15. Jenkins, P. T., and Reinganum, C. 1965. The occurrence of a quiescent infection of stone fruits caused by Sclerotinia fructicola (Wint.) Rehm. Aust. J. Agric. Res. 16:131-140.

16. Jerome, S. M. R. 1958. Brown rot of stone fruits: Latent contamination in relation to spread of the disease J. Aust. Inst. Agric. Sci. 24:132-140.

17. Kable, P. F. 1965. Air dispersal of conidia of Monilinia fructicola in peach orchards. Aust. J. Exp. Agric. Anim. Husb. 5:166-171.

18. Kable, P. F. 1969. Brown rot of stone fruits on the Murrumbidgee Irrigation Areas I. Aetiology of the disease in canning peaches. Aust. J. Agric. Res. 20:301-316.

19. Kable, P. F. 1971. Significance of short-term latent infections in the control of brown rot in peach fruits. Phytopathol. Z. 70:173-176.

20. Kennedy, J. B., and Neville, A. M. 1986.
Basic Statistical Methods for Engineers and Scientists. 3rd ed. Harper \& Row, New York.

21. Lack, K. J. 1989. The spread of apple brown rot (Monilinia fructigena) by insects. Ann. Appl. Biol. 115:221-227.

22. Landgraf, F. A., and Zehr, E. 1982. Inoculum sources for Monilinia fructicola in South Carolina peach orchards. Phytopathology 72:185-190.

23. Margosan, D. A., and Phillips, D. J. 1985. Effect of two temperatures on nuclear number of conidia of Monilinia fructicola. Mycologia 77:835-837.

24. Margosan, D. A., and Phillips, D. J. 1989. Effect of temperature and high sugar concentrations on spore size of Monilinia fructicola. Mycologia 81:293-295.

25. Michailides, T. J., and Spotts, R. A. 1990. Transmission of Mucor piriformis to fruit of Prunus persica by Carpophilus spp. and Drosophila melanogaster. Plant Dis. 74:287-291.

26. Northover, J., and Cerkauskas, R. F. 1994. Detection and significance of symptomless latent infection of Monilinia fructicola in plums. Can. J. Plant Pathol. 16:30-36.

27. Ogawa, J. M. 1957. The dried fruit beetle disseminates spores of the peach brown rot fungus. (Abstr.) Phytopathology 47:530.

28. Ogawa, J. M., and English, H. 1991. Diseases of Temperate Zone Tree Fruit and Nut Crops. University of California, Division of Agriculture and Natural Resources Publication 3345 .

29. Osorio, J. M., Adaskaveg, J. E., and Ogawa, J. M. 1993. Comparative efficacy and systemic activity of iprodione and the experimental anilide E-0858 for control of brown rot on peach fruit. Plant Dis. 77:1140-1143.

30. Peck, C. H. 1881. Report of the botanist. Rep. N.Y. State Mus. Nat. Hist. 34:34-36.

31. Phillips, D. J. 1984. Effect of temperature on
Monilinia fructicola conidia produced on fresh stone fruits. Plant Dis. 68:610-612.

32. Phillips, D. J., and Margosan, D. A. 1985 Glucose concentration in growth media affects spore quality of Monilinia fructicola. (Abstr.) Phytopathology 75:1285.

33. Phillips, D. J., Margason, D. A., and Mackey, B. E. 1989. Volume, nuclear number, and aggressiveness of conidia of Monilinia fructi cola produced on media of varied glucose concentrations at 15 and $25^{\circ} \mathrm{C}$. Phytopathology 79:401-403.

34. Poulos, P. L., and Heuberger, J. W. 1952. Relation of wounds to the fruit rot phase of the brown rot disease of peaches. Plant Dis. 36:198-200.

35. Tate, K. G., and Corbin, J. B. 1978. Quiescent fruit infections of peach, apricot, and plum in New Zealand caused by the brown rot fungus Sclerotinia fructicola. N.Z. J. Agric. 6:319325.

36. Tate, K. G., and Ogawa, J. M. 1975. Nitidulid beetles as vectors of Monilinia fructicola in California stone fruits. Phytopathology 65:977-983.

37. Wade, G. C. 1956. Investigations on brown rot of apricots caused by Sclerotinia fructicola (Wint.) Rehm. I. The occurrence of latent infection in fruit. Aust. J. Agric. Res. 7:504 515.

38. Wade, G. C., and Cruickshank, R. H. 1992 Rapid development of resistance of wounds on immature apricot fruit to infection with Monilinia fructicola J. Phytopathology 136:89-94.

39. Wade, G. C., and Cruickshank, R. H. 1992 The establishment and structure of latent infections with Monilinia fructicola on apricot. J. Phytopathology 136:95-106.

40. Zehr, E. I. 1982. Control of brown rot in peach orchards. Plant Dis. 66:1101-1105. 